\title{
Populism and Layers of Social Belonging: Support of Populist Parties in Europe
}

\author{
Alexander Langenkamp ${ }^{1 *}$, Simon Bienstman ${ }^{1}$ \\ *corresponding author: \\ langenkamp@soz.uni-frankfurt.de \\ ${ }^{1}$ Faculty of Social Science - Institute of Sociology, \\ Goethe University Frankfurt
}

\begin{abstract}
Although scholars hypothesised early on that social belonging is an important predictor for voting behaviour, its role for populist voting remains empirically ambiguous and underexplored. This contribution investigates how different aspects of social belonging, i.e. quality, quantity and perception of one's own social relationships, relate to electoral abstention and to populist voting on the left and right. Employing multilevel regression models using data from four waves of the European Social Survey, this study finds that all measures of social belonging foster turnout, but exert an incoherent influence on populist voting depending on the party's ideological leaning. While social belonging plays a subordinate role for left populist support, strong social belonging reduces the probability to support populist parties on the right. With that, the study analysis offers a nuanced view on how different dimensions of social belonging relate to electoral behaviour. By doing so, this study sheds light on what aspects of social belonging encourage, or inhibit, which form of "protest at the ballot box."
\end{abstract}

\section{Introduction}

Not every crisis appears suddenly. For decades, sociodemographic trends such as rising individualism, aging societies, smaller household sizes, shrinking social networks, and widespread loneliness led experts to warn that social belonging will become a growing issue for western democracies (Buecker et al., 2021; Cacioppo \& Cacioppo, 2018b; Olds \& Schwartz, 2009). Media reports picked up these warnings and framed it as an emerging "epidemic of loneliness" and first governments put the issue on their official agenda (Easton, 2018; Yeginsu, 2018). Alongside concerns about consequences for well-being and public health, some authors 
[Hier eingeben]

drew the connection between this creeping crisis of social belonging, atomized societies, and the rise of populism, stating that lonely individuals are a vulnerable target group for extremist and populist parties (Buechler, 2013; Hertz, 2021).

However, despite the uncontested view that social relationships play an important role in voter mobilization and political decision-making, a person's social belonging is only rarely considered in empirical models explaining populist party preference (Stockemer et al., 2018). If considered, authors operationalize it with classic measures of social capital, i.e. number of social contacts, group membership, or generalized trust, and investigate its association with electoral right-wing support (Berning \& Ziller, 2017; Zhirkov, 2014). ${ }^{1}$

This operationalization faces two major limitations. First, it ignores other important dimensions of social belonging such as the quality of these relationships or the perceived relative social activity compared to similar others. Secondly, despite rapidly growing interest in populism, the question of whether different dimensions of social belonging exert a uniform or heterogeneous influence on populist party support on the left and right end of the political spectrum remains underexplored.

Despite an ambivalent empirical picture, it is commonly assumed that social capital, social ties, or emotional belonging foster electoral turnout and exert a homogeneous (shielding) effect against populism, independent of the party's position on the political spectrum (Rydgren, 2011). However, it is far from obvious that these dimensions of social belonging exert a uniform influence on populist parties on the left and the right. Our argument is based on the premise that the right- and left-populist narratives correspond to a different degree with the affective needs of individuals with weak social belonging, which leads to a heterogeneous relationship between belonging and support for populist parties depending on their ideological standing.

\footnotetext{
${ }^{1}$ A noteworthy exception is a paper from Rydgren (2009), which finds only marginal predictive power of social relations for right-wing voting. However, the analysis relies on data from the early 2000 s, a period with substantially fewer populist voters. As the author notes, in five considered countries, the number of populist voters varied between 57 and 249 cases. Hence, the results potentially stem from limited observations.
} 
[Hier eingeben]

By investigating to what extent different dimensions of social belonging are associated with right-populist support, left-populist support, or nonvoting, this study aims to fill this gap in the literature. Seen as voice and exit strategies for political discontent (Wingrove \& Hirschman, 1971), the analysis offers a nuanced view on how subjective and objective dimensions of relationships relate to electoral behaviour. By doing so, the study sheds light on what aspects of social belonging encourage, or inhibit, which form of "protest at the ballot box".

To that end, we first review the concept of populism and discuss commonalities and differences between left- and right-wing populist parties. Second, we review why social belonging is commonly expected to shield from nonvoting and populist party support in general. Third, we extend this prevailing view by arguing why social belonging is expected to exert an inconsistent effect on populist parties on the left and right. Finally, we put our argument to an empirical test by utilizing four waves (6-9) of the European Social Survey.

The analysis suggests that interpersonal aspects of social belonging, 1) the quality of social relationships, 2) contact frequency and 3) the relative perception of one's social activity compared to others, foster turnout and decrease the probability of voting for right-wing populist parties. In contrast, the three interpersonal aspects play a subordinate role for left-wing populist parties as only contact frequency is weakly and negatively associated with supporting left-wing populist parties. Finally, formal group membership increases turnout and reduces the probability to vote for populist parties independent of their ideological leaning. This indicates that, while social belonging generally increases turnout, different measures of social belonging exert disparate effects on the support of populist parties depending on their ideological underpinning. In the greater picture, the results suggest that eroding belonging has not only a demobilizing, but also a polarizing effect.

\section{Populism and host ideologies: Commonalities and differences}


[Hier eingeben]

Multiple electoral successes of populist parties and corresponding growing media coverage led to substantial growth in research concerned with populist voting (Bernhard \& Kriesi, 2019; Matthijs Rooduijn, 2019). In Europe, political populism is most often associated with the radical right and, consequentially, most studies focus on right-leaning populist parties (Mudde, 2007). However, the successes of populist parties on the left side of the political spectrum raise questions about whether insights about right-wing populism can be generalized to the populist left (Damiani, 2020).

Although populism is a contested concept (Hunger \& Paxton, 2021), most studies define populism as a thin ideology with a conceptual core that can be linked to various host ideologies (Mudde \& Kaltwasser, 2017). This study follows this ideational approach of populism as it provides a useful framework to conceptualize the shared core of populist parties as well as the ideological differences between parties on the left and right, which in turn explain potential differences in the relationship between weak social belonging and populist party support.

With respect to the shared conceptual core, populist parties and leaders typically utilize dividing rhetoric stating that society consists of two antagonistic groups. On the one side the righteous people, on the other side the misguided and corrupt elites (Ivaldi et al., 2017; Mudde, 2004). This narrative encapsulates three central ideas. First, an anti-pluralistic view of civil society as a homogeneous and cohesive population. Second, a universally shared "will of the people". Third, a small and corrupted elite that opposes the will of the people.

The conceptual core of populist parties explains empirical findings that the electoral base of populist parties on the left and right have a similar socio-economic profile with respect to lower education, weaker socioeconomic position, and economic or political discontent (Kaltwasser \& Van Hauwaert, 2020; Matthijs Rooduijn, 2018; Matthijs Rooduijn et al., 2017). In line with that, prominent explanations for populist voting are the "losers of modernization" and "cultural backlash" perspectives (Gidron \& Mijs, 2019; Hartmann et al., 2021; Norris \& Inglehart, 2019). 
[Hier eingeben]

Going beyond the conceptual core, populism can be coupled with various political 'host ideologies' on the left and right whose worldviews and political goals are largely diametrically opposed. Depending on this host ideology, parties can vary in their concept of who belongs to "the people", who belongs to the opposing elite, and how society should be organized based on the general will of the people (Ivaldi et al., 2017; Mudde \& Kaltwasser, 2017). Therefore, due to the varying host ideologies, populist parties differ in their socio-psychological messaging and vision of how society should develop in the future. Following this reasoning, populist parties can be differentiated in aspects that are associated with their historical ideological roots and their stance on social change.

The opposing ideological view on social change and corresponding communicated messages are of particular importance for this study. As will be argued in more detail later on, we theorize that the opposing ideological narratives correspond to different degrees with the affective needs of individuals with weak social belonging. Left- and right-populist parties differ in their envisioned direction the society should develop. Societal pessimism, law and order narratives, and a nostalgia for the past are important characteristics of right-wing messaging (Steenvoorden \& Harteveld, 2018). In line with that, right-wing populist parties represent authoritarian, conservative and protectionist values (Göpffarth, 2021; Mudde, 2007). With that, right-wing populism typically promotes social change in the sense of preservation and reconstitution of old values from "better times of the past", while taking a stance against progressive social change pursued by liberal elites.

In contrast, left-populist parties promote progressive social change, tend to reject the current capitalist, socio-economic structure, and envision alternative economic and social systems (Damiani, 2020; March, 2012). With that, they represent social change in terms of a new social order, financial redistribution, and cultural pluralism (Ivaldi et al., 2017). This corresponds with their appeal for people experiencing perceived economic hardship (Gidron and Mijs, 2019). Likewise, studies investigating the association between values and left-right ideological 
[Hier eingeben]

positioning confirm that political orientation and basic human values are interlinked, suggesting that right- and left-wing voters differ in their personal values and needs (Norris \& Inglehart, 2019; Schwartz et al., 2010).

These differences become apparent in studies comparing party manifestos of populist parties (March, 2017). For instance, in the British case, populist parties on the left and right alike present themselves as popular identities in juxtaposition to antagonistic elites. However, the party manifestos also indicate that right wing populist parties are characterised by a strong people-centrism and anti-immigrant stance. In contrast, left wing parties focus on more traditional social divides such as social class and inequality. Furthermore, "left-wing populists are even more inclined to devote attention to particularist constituencies whose interests diverge from those of the people as a whole, such as the unemployed (both parties); women, the disabled and LGBT groups (especially the SSP); and immigrants and religious (especially Muslim) minorities (Respect).” (March, 2017 p.294-295). Many of these findings are mirrored by studies analysing populist parties in other countries as well (Bernhard \& Kriesi, 2019; Castanho Silva, 2017; Matthijs Rooduijn \& Akkerman, 2017).

These reviewed similarities and differences between populist parties raise two questions this contribution aims to investigate. First, how social belonging relates to voting behaviour, i.e. nonvoting and populist voting in general. Second, how social belonging corresponds with the varying messaging of populist parties on the left and right. While the next chapter focuses on the first question and links the consequences of weak social belonging to the conceptual core of populism, the subsequent chapter elaborates on the latter by linking the affective needs of poorly included individuals to the ideological narratives of left- and right-wing populist parties.

\section{Social belonging, electoral abstention and populist party support}

Considering the first question, sociological and psychological perspectives help to explain why social belonging, or perceived lack thereof, causes a lower probability to vote and is expected 
[Hier eingeben]

to cause an increased propensity to vote for populist parties in general. As reviewed by Rydgren (2011), scholars in the tradition of mass society theory argue that modern democracies are characterized by an increasing atomization of society. This causes a structural erosion of social networks and social capital which leads, in consequence, to two central outcomes. First, citizens lose their social support network that provides important resources vital for political participation. Second, on an emotional level, they lose their sense of community, security and belonging. While the first outcome offers an explanation for why weak social embeddedness might be associated with political demobilisation, the latter highlights the role of social belonging for electoral support of populist and radical parties.

The resource-based perspective builds on the premise that turnout can be understood as a function of motivation to vote, ability to vote, and costs of voting (Harder \& Krosnick, 2008). While scholars have found countless predictors for voter turnout (Smets \& van Ham, 2013), social ties and social networks play a prominent role as they provide important resources such as economic support, information, and social control via reinforcing social norms which foster motivation and ability to participate (Bhandari \& Yasunobu, 2009; Bhatti et al., 2020).

The second link is based on socio-psychological mechanisms. Social belonging is a fundamental human desire (Baumeister \& Leary, 1995) and a weak sense of community and belonging motivates individuals to seek out interpersonal relationships and groups that provide meaning, belonging, and shared identity (Qualter et al., 2015; Spithoven et al., 2017). Given that populist parties promote the concept of a unified, homogeneous society and provide an ideological identity, poorly integrated individuals are likely to respond to this narrative.

Furthermore, authors in the tradition of social capital theory state that a strong sense of belonging and inclusion in communal networks or organizations foster social trust, civic virtues, and tolerance (Olson, 1972; Putnam, 2000), which reduces receptiveness to the friendor-foe paradigm of populist parties and promotes electoral turnout as a civic duty in democratic 
[Hier eingeben]

societies (Blais \& Achen, 2019). Therefore, belonging can be expected to increase both the propensity to turn out as well as the probability to turn out for a party that does not draw on populist strategies.

Linking the summarized arguments together, weak social belonging can be expected to generate a stronger affinity to populist parties as well as a higher probability to abstain from elections. In line with that reasoning, recent studies highlighted that both social ties and perceived loneliness are relevant predictors of abstention/participation (Bhatti et al., 2020; Langenkamp, 2021).

H1: Weak social belonging is positively related to populist party support.

$\mathrm{H} 2$ : Weak social belonging is positively related to nonvoting.

\section{Psychological consequences of belonging and ideological narratives}

After deriving the argument why weak social belonging should foster populist voting and reduce electoral turnout, this chapter extends this view and derives why the affective needs of individuals with weak belonging likely correspond to a different degree with the preservationprogress distinction of populist left- and right-wing parties. This question can be answered by linking the psychological consequences of weak social belonging to the ideological narratives of the right- and left-wing populist parties reviewed before.

From an evolutionary psychological perspective (Cacioppo \& Cacioppo, 2018a; Spithoven et al., 2017), being included in a social group provides resources such as food, security, and support that are essential for survival. As humans are inherently social beings, losing this social support structure was life-threatening for most of human history. Loneliness is the emotional response to the perception that one's social support network is qualitatively or quantitatively insufficient and serves to motivate people to re-affiliate with others (Qualter et al., 2015). As such, loneliness is not a mere product of the quantity of social contact but rather depends on an 
[Hier eingeben]

interplay of norms, social comparisons with relevant others, and the desired quantity and quality of social ties (Gierveld et al., 2018).

Being unresolved, loneliness is associated with numerous emotional and psychological outcomes. Among others, lonely individuals are more likely to desire for shared identity, community, and re-affiliation (Qualter et al., 2015), while they also tend to suffer from increased social anxiousness, more negative expectations of future events, increased fear of being negatively perceived by others, and lower social trust (Cacioppo et al., 2006; Rotenberg et al., 2010). Likewise, loneliness is associated with prevention-oriented goals instead of promotion-oriented goals (Spithoven et al., 2017).

As illustrated earlier, populist parties of the left and right build on the same conceptual core (i.e. corrupt elites who betray the "common will" of the people), while at the same time coupling this thin ideology with different host ideologies. Correspondingly, populist parties differ in their messaging how they aim to solve social issues and which vision they have for society depending on their ideological roots. The right-wing populist narrative typically builds on a traditionalist worldview that aims for the preservation of the old and reduction of uncertainty, which likely corresponds with the affective reactions to loneliness. In line with that reasoning, studies were able to show that lonely individuals tend to endorse politically conservative values and that citizens who live in societies with low social cohesion are more likely to hold racist beliefs (Caller \& Gorodzeisky, 2021; Floyd, 2017). Likewise, given that individuals with weak social belonging seek community, unity, and security, these desires are likely to correspond with the strong people-centric (nativist) rhetoric of right-wing populist parties in particular (March, 2017).

If this holds true, weak social belonging should be positively associated with right-wing populism, as it answers directly to the affective need of lonely individuals to protect themselves and avoid insecurity. In contrast, the narrative of the populist left contains goals of progressive, 
[Hier eingeben]

transformative policies that are unlikely to correspond with the anxious and security seeking affective reaction of lonely individuals. Likewise, their focus on progressive social groups, social diversity and minorities might not correspond with the mentioned tendency towards conservatism of individuals with weak social belonging.

This proposition is in line with recent research showing that, while populist voters are very similar in terms of life satisfaction, discontent, and frustration (about the political system and the economic situation), it is the combination of these emotions and generalized social trust that sets populist left and right voters apart (Yann et al., 2019). Whereas those who vote for the populist left have high levels of trust, populist right voters and absentees are particularly distrusting. According to Yann et al., this subjective-emotional dimension has become a decisive factor in whether one casts a vote for the left or right because it structures a person's outlook on the world and, consequently, political values and orientations (especially concerning anti-immigrant sentiment and questions of redistribution). Since weak social belonging and loneliness foster distrust and anxiety (Cacioppo et al., 2006; Rotenberg et al., 2010) these arguments further support the notion of heterogeneous effects of social belonging on populist voting.

H3: Weak social belonging at the individual level is positively associated with right-wing populism, but not with left-wing populism.

\section{Data and Methods}

Individual-level data come from the European Social Survey (ESS). We pool rounds 6 to 9 of the ESS to maximize the sample of populist voters. The four waves cover an observation period from 2012 to 2018.

The dependent variable is based on two retrospective vote variables. Respondents were asked whether they voted in the last national election and if that is answered in the affirmative, 
[Hier eingeben]

which party they voted for. We use this information to distinguish persons who did not vote (including Blanco and non-valid votes) and persons who voted for either any populist party, a populist left party, a populist right party, or a mainstream party. The populist party classification is based on The PopuList 2.0 (Rooduijn et al., 2019), a dataset resulting from the collaborative efforts of journalists and academic experts. There, parties classify as populist when they fit the following definition: "Parties that endorse the set of ideas that society is ultimately separated into two homogeneous and antagonistic groups, "the pure people" versus "the corrupt elite," and which argues that politics should be an expression of the volonté générale (general will) of the people (Mudde 2004)." We use the PopuList's record of parties' host ideologies to distinguish between parties that are populist far-left and populist far-right parties. Far left and far right non-populist parties are excluded from all analyses. We treat as mainstream parties those that are not populist. Parties that are populist but without a clear host ideology, so-called ‘valence populism' (Zulianello, 2020), are included in our first analysis concerned with populist voting independent of underlying ideology ( $\mathrm{H} 1$ and $\mathrm{H} 2)$, but are not part of our analysis of populist party support differentiated by ideology $(\mathrm{H} 3)$. A list of populist parties included in our analysis is provided in Table 5 in the Online Appendix.

As for indicators for social belonging at the individual level, we include contact frequency, subjective relative social activity, and relationship quality. Contact frequency is measured by the following question: "[...] How often do you meet socially with friends, relatives, or work colleagues?" Respondents then indicate on a seven-point scale whether they meet never, less than once a month, several times a month, once a week, several times a week, or every day. Relative social activity measures on a five-point scale whether respondents take part in social activities "much less than most", up to "much more than most" other people of their age. The quality of social relationships is measured with a seven-point scale asking the participants "How many people, if any, are there with whom you can discuss intimate and personal matters?" With that, we capture the frequentist dimension, the mental relative representation of one's social 
[Hier eingeben]

relationships compared to the larger social environment, and the quality of the available social relationships. Given the importance of formal group networks for identity formation, social capital, and local integration, we further include group membership as fourth indicator for social belonging. We measure formal group membership with a dummy for respondents who are currently in a trade union, an organization or association other than parties and activist groups, or in a religious community. The latter is a dummy variable for persons who attend religious services at least once a month, indicating a certain degree of integration in religious communities. Taken together, this selection of variables covers multiple important dimensions of social belonging on the individual level.

To investigate the relationship between belonging and voting behaviour, we considered several additional covariates. Most importantly, we control for the respondent's age, gender, education, and income as these sociodemographic characteristics are well-established confounders in the literature (Rooduijn, 2018). We recode the income measure to quintiles of the country's income distribution and add an additional category to retain cases with missing income information. Educational level is measured by the International Standard Classification of Education, distinguishing those with none or primary education (ISCED 0-1), lower secondary (ISCED 2), upper secondary and higher non-tertiary education (ISCED 3-4), or tertiary education (ISCED 5-6). Because a migration background has previously been found to be related to both civic participation and voting behaviour (Strijbis, 2014), we also include a dummy indicating whether respondents or any of their parents were not born in the country of residence. In addition, we control for household size (top-coded at 10 persons), unemployment, and political orientation measured by the eleven-point left-right scale. Descriptive statistics for all variables are provided in Table 1.

We fit linear probability models with country and wave (i.e. "two-way"-) fixed effects and heteroscedasticity-robust standard errors. We do so for each type of electoral behavior 
[Hier eingeben]

contrasted against voting for a mainstream party. In the first part of the analysis, we model the effects of social belonging on undifferentiated populist voting and nonvoting. In the second part, we differentiate between the ideological positions of populist parties.

After excluding respondents who were not eligible to vote in the reference election as well as those with missing information on any of the variables in the analysis, we retain a sample of 25 countries and 100795 respondents in the analyses of nonvoters and 95866 respondents in 25 countries in the models for general populism. The analysis of the populist left is based on 7 countries $(\mathrm{N}=32881)$, that for the populist right on 22 countries $(\mathrm{N}=80904$, see also Table 7 in the Online Appendix). The number of populist left voters ranges from 20 in the United Kingdom to 683 in Germany. For the populist right, this ranges from seven in Lithuania to 2330 in Hungary.

\section{[Table 1 near here]}

\section{Results}

We begin our analysis by investigating the relationship between social belonging and electoral protest by keeping the populist voting variable undifferentiated. Since we are interested in the effects of social belonging on the probability to vote for a populist party or to abstain from voting, we do not discuss the control variables in further detail but show complete results in Table 3 in the Appendix. Figure 1 displays the standardized parameter estimates of the final linear probability models concerned with Hypotheses 1 and 2.

\section{[Figure 1 near here]}

The results show a clear effect of social belonging on nonvoting. Relative social activity, contact frequency, relationship quality and formal group involvement all significantly increase the probability to vote $(p<.001)$. Formal group involvement exerts a strong effect on turnout, as group members are roughly 7.2 percent more likely to vote compared to non-members. In 
[Hier eingeben]

comparison, every standard deviation increase in perceived relative social activity increases the probability for turnout by 2.2 percent, accumulating to a maximum effect of 9.64 percent over the whole scale. This highlights that all four exert a substantial effect on turnout, even under the control of one another.

In the model contrasting populist voters and mainstream voters, the results show a uniformly negative effect. All social belonging indicators reduce the probability to vote for a populist party, although the effect sizes are smaller compared to their influence on turnout. The separate indicators for interpersonal relationships decrease the probability to vote for a populist party by 0.3 to 0.7 percent per standard deviation. The predicted difference in the probability to vote for a populist party instead of a center party between individuals with the lowest and highest standardized relative social activity scores is 2.07 percent, ceteris paribus. For contact frequency, this is 2.59 , and for relationship quality 1.13 . Being a member of a religious community, trade union or another voluntary organization reduces the probability to vote for a populist party by 1.84 percent. As the absolute values of the effect sizes do not appear large at first, it is important to put them into perspective by comparing them with other well-established predictors as a benchmark. For instance, the accumulated effect of relative social activity is about half as strong as unemployment $(\beta=0.042)$ or education (where having a university degree compared to none or primary education decreases the probability to vote for a populist party by 4.8 percent)

Our analysis so far supports the general notion that social belonging fosters voter turnout and, to slightly lesser degree, shields from casting a vote for populist parties. As we have argued, social inclusion might have disparate effects on populist voting depending on party ideology. The subsequent analysis aims for a more differentiated view on the consequences of social belonging for electoral behavior. To test Hypothesis 3, we fit separate models for leftand right-wing populism. Figure 2 shows the relevant standardized parameter estimates of the 
[Hier eingeben]

final models for the three types of electoral protest (for the complete results, see Table 4 in the Appendix). Note that the model for nonvoting is unchanged and is included for reference only.

\section{[Figure 2 near here]}

The central insight of the differentiated analysis is the heterogeneous effect of social belonging for populist parties on the left and the right. In line with the previous results reported in Figure 1, Figure 2 shows that social belonging is negatively and significantly related to voting for a populist right party, irrespective of the specific indicator. Contact frequency and relationship quality decrease the probability to vote for a populist right vs. a mainstream party by 0.4 percent per unit increase. The effect of relative social activity is slightly larger $(\beta=-0.007, p<0.001)$.

However, the results for left-wing populist voting deviate from the findings reported in Figure 1. Among the indicators for interpersonal relationships, the results indicate that only contact frequency $(\beta=-0.009, p<0.001)$ reduces the probability to vote for a populist left party, whereas the other indicators have null effects. Interestingly, while perceived relative social activity is just shy of statistical significance ( $\mathrm{p}=0.094)$, it is the only predictor suggesting a positive effect on left-populist voting. While insignificant effects should not be overinterpreted, it illustrates the deviating pattern for left populist voting.

Likewise, formal group membership is associated with a reduced probability to vote for right- as well as left-wing populist parties alike. The results indicate a small negative effect on right-wing populist voting $(\beta=-0.006, \mathrm{p}=0.007)$ and a slightly stronger effect on left-wing populist voting $(\beta=-0.016, \mathrm{p}<0.001)$. Group membership, therefore, has a smaller effect on right-wing populist voting than on left-wing populist voting. This is, however, most likely due to the indicator capturing membership in a religious community, which negatively correlates with left-wing voting but has, in some Central and Eastern European countries such as Poland and Hungary, a positive correlation with support for the populist right. 
[Hier eingeben]

Taken together, we find that, on average, group membership reduces the probability to vote for a populist party on the left and right. However, more research is needed to differentiate under what circumstances some kind of group membership may actually be detrimental to democratic support. In light of research concerned with mobilization networks of radical groups, it is likely that social groups can potentially mobilize populist voters under certain circumstances and hence should be considered negative social capital (Caiani, 2017; Doosje et al., 2016; Klandermans \& Mayer, 2005). To summarize, the second part of our analysis shows that, whereas social belonging is beneficial for turnout per se, it depends when it comes to voting for populist parties. There are some indicators of belonging, such as group membership and contact frequency, which reduce the probability to vote for populist parties independent of ideology. Other dimensions, however, such as relative social activity and relationship quality, are more differentiated between populist right and populist left parties. Overall, our analyses suggest that social belonging plays an important role in voter mobilization and right-wing populist support, while it is of lesser importance for left-wing populist party support. Considering that we find these results under control of a range of covariates, as well as the interrelationships between the separate indicators of social belonging, this is a clear indication that social belonging affects populist voting and that it does so in different ways, depending on the host ideology.

\section{Robustness Checks}

When using alternative specifications, most of the estimates were highly robust and differed, if at all, only minimally from our main models. Not controlling for political orientation did not alter any of the models substantially. When we included a social trust index composed of respondents' assessment of people's fairness, helpfulness, and trustworthiness (0.77), the coefficient for relationship quality in both the model of undifferentiated populism and rightwing populism turned insignificant. The other social belonging effects also became slightly 
[Hier eingeben]

smaller but remained significant. While this indicates that social trust functions as a mediator, these results show that social belonging has an independent effect on (right-wing) populism. Controlling for an index of immigration attitudes (0.86), composed of questions capturing respondent's assessment of immigration's effect on the economy, the cultural life and general living conditions, relationship quality, and group membership became insignificant in the model for right-wing populism. Relationship quality also turned insignificant in the model for undifferentiated populism. The other estimates remained robust in this specification. However, given that the stance on immigration is one of the most salient differences between right- and left-wing populist parties, it is of little surprise that some coefficients in the models drop out of significance. Moreover, since conservative values and racist beliefs are related to feelings of loneliness and social cohesion (Caller \& Gorodzeisky, 2021; Floyd, 2017), immigration attitudes may be regarded as mediating the relationship between social belonging and populist voting.

In a final specification, we refit the main models while additionally controlling for the place of residence (urban vs. rural), for a respondent's confession (Christian vs. other), and for social class instead of income (operationalized following Oesch (2006)). In the model for populist voting, this led the relationship quality indicator to become insignificant. This specification also reduced the effect of group membership on all types of populist voting, turning it insignificant in the model for right wing populism. Most likely, this is because the Christianity indicator takes over the effect of being in a religious community. The corresponding Tables 6-9 are in the online appendix. These changes do, however, not lead us to modify our substantive conclusions.

We further re-estimated each of the final models while excluding one country at a time ('jackknifing') in order to make sure that the results were not overly influenced by a single country (see Tables 10-13 in the Online Appendix). The results are generally robust, except for 
[Hier eingeben]

the coefficient for relationship quality in the model of populism, which remains negative but does not reach significance in 8 out of 26 specifications. For the same model, we find that the group membership coefficient turns insignificant when Austria, Switzerland, Germany, or the Netherlands are excluded. We do not regard these results as a refusal of our theory since the other coefficients remain highly robust and removing a large number of cases from any statistical analysis naturally reduces its power.

\section{Discussion}

Developments such as shrinking household sizes, dwindling membership in social organisations, eroding social networks, and widespread loneliness have led experts to warn of an emerging crisis of social belonging (Cacioppo \& Cacioppo, 2018b; Holt-Lunstad, 2017). While consequences for health and well-being are well-established, our results suggest that these developments relate to voter turnout and support of populist parties as well.

Overall, our analysis indicates that strong social belonging does indeed foster voter turnout and protects from supporting right-wing populist parties. However, our findings highlight that social belonging does not shield from populism per se and that generalizing insights across variants of populism is of limited use for our understanding of political behaviour. While social belonging on the individual level is just weakly and inconsistently associated with support for the populist left, it plays an important and homogeneous role in voting populist parties on the right. This highlights once more the importance of considering the host ideology of populist parties.

That being said, formal group membership plays a special role in this dynamic, as it seems to mobilize voters and shield from populist voting independent of the underlying ideology. This is in line with the expectations of social capital theory. However, this also highlights that the other considered indicators of social belonging are not interchangeable, but exert an independent effect on voting behaviour. 
[Hier eingeben]

With that, our study adds to the literature in multiple ways. First, the results qualify earlier studies based on survey data from the early 2000s that did not find a relationship between social inclusion and populism (Rydgren, 2009). As more populist parties have emerged since then, our analysis of more recent data suggests that social belonging as a predictor for populist attitudes should not be discarded. On the contrary, our finding that weak social belonging is associated with electoral demobilization, as well as polarization, suggests an interesting dynamic between belonging and voice and exit strategies for political discontent (Wingrove \& Hirschman, 1971). With that, this study is in line with other recent accounts from the social marginalization literature that show that perceived social marginalization, i.e. lack of strong attachment to norms and social engagement, fosters political alienation and support for radical parties (Gidron \& Hall, 2020).

Second, the results highlight that conclusions about right-wing populism cannot easily be generalized to left-populist parties. While certain similarities are present due to the shared populist ideology, the vastly different host ideologies make effect heterogeneity in respect of mobilizing factors very likely. Thus, upcoming studies might consider reinvestigating which predictors do explain populist voting in general or only apply for parties with specific ideological underpinning.

Third, we demonstrated that disentangling different dimensions of social belonging can bring potential benefits in comparison to bundling measures into rough scales for reasons of simplicity and statistical power. That being said, our analysis and conclusions should be interpreted in light of several limitations. First, as we used multiple waves of cross-sectional data, the analysis is based on statistical associations and cannot empirically test causality. While we believe that these results are informative as they point to new fields of investigation, we believe it is important to recognise this issue in order to interpret the findings appropriately. Secondly, the concept of populism is still debated and the decision of which party should be 
[Hier eingeben]

labeled as left or right populist is difficult (Hunger \& Paxton, 2021). Our operationalization relied on a widely used and well-established dataset and we are confident that this is the most feasible procedure with respect to reliability and comparability across studies. Still, we acknowledge this issue.

Fourth, this study puts emphasis on demonstrating that the relationship between belonging and populist voting (in particular on the right side of the political spectrum) is theoretically sound, empirically robust and substantial in size. However, the analysis does not directly investigate the question of why this relationship is heterogeneous for left- and right-wing populist parties and should therefore be seen as starting point for future research.

While implications for greater societal developments have to be drawn with caution, we believe that our results speak to the general debate on how sociodemographic trends influence elections in the long run. Socio-demographic developments and a corresponding eroding sense of belonging and widespread loneliness might not only reduce voter turnout but also benefit right-wing populism in particular.

\section{Data Accessibility Statement}

The $\mathrm{R}$ code used for the analysis will be made available upon publication. 
[Hier eingeben]

\section{Literature}

Baumeister, R. F., \& Leary, M. R. (1995). The Need to Belong: Desire for Interpersonal Attachments as a Fundamental Human Motivation. Psychological Bulletin. https://doi.org/https://doi.org/10.1037/0033-2909.117.3.497

Bernhard, L., \& Kriesi, H. (2019). Populism in election times: a comparative analysis of 11 countries in Western Europe. West European Politics, 42(6). https://doi.org/10.1080/01402382.2019.1596694

Berning, C. C., \& Ziller, C. (2017). Social trust and radical right-wing populist party preferences. Acta Politica, 52(2). https://doi.org/10.1057/ap.2015.28

Bhandari, H., \& Yasunobu, K. (2009). What is social capital? A comprehensive review of the concept. In Asian Journal of Social Science (Vol. 37, Issue 3). https://doi.org/10.1163/156853109X436847

Bhatti, Y., Fieldhouse, E., \& Hansen, K. M. (2020). It's a Group Thing: How Voters go to the Polls Together. In Political Behavior (Vol. 42, Issue 1). Springer US. https://doi.org/10.1007/s11109-018-9484-2

Blais, A., \& Achen, C. H. (2019). Civic Duty and Voter Turnout. Political Behavior, 41(2). https://doi.org/10.1007/s11109-018-9459-3

Buechler, S. M. (2013). Mass Society Theory. In The Wiley-Blackwell Encyclopedia of Social and Political Movements. https://doi.org/10.1002/9780470674871.wbespm473

Buecker, S., Mund, M., Chwastek, S., Sostmann, M., \& Luhmann, M. (2021). Is Loneliness in Emerging Adults Increasing Over Time? A Preregistered Cross-Temporal Meta-Analysis and Systematic Review. Psychological Bulletin, 1-60. https://doi.org/10.1037/bul0000332.supp

Cacioppo, J. T., \& Cacioppo, S. (2018a). Loneliness in the Modern Age: An Evolutionary 
[Hier eingeben]

Theory of Loneliness (ETL). In Advances in Experimental Social Psychology (Vol. 58). https://doi.org/10.1016/bs.aesp.2018.03.003

Cacioppo, J. T., \& Cacioppo, S. (2018b). The growing problem of loneliness. In The Lancet (Vol. 391, Issue 10119). https://doi.org/10.1016/S0140-6736(18)30142-9

Cacioppo, J. T., Hawkley, L. C., Ernst, J. M., Burleson, M., Berntson, G. G., Nouriani, B., \& Spiegel, D. (2006). Loneliness within a nomological net: An evolutionary perspective. Journal of Research in Personality, 40(6). https://doi.org/10.1016/j.jrp.2005.11.007

Caller, S., \& Gorodzeisky, A. (2021). Racist views in contemporary European societies. Ethnic and Racial Studies, O(0), 1-22. https://doi.org/10.1080/01419870.2021.1952289

Castanho Silva, B. (2017). Contemporary Populism: Actors, Causes, and Consequences Across 28 Democracies. 1-256. message:\%3CDB6PR08MB266109C5E81EBF9749E7340AD4C00@DB6PR08MB2661 .eurprd08.prod.outlook.com\%3E

Damiani, M. (2020). Populist Radical Left Parties in Western Europe. In Populist Radical Left Parties in Western Europe. https://doi.org/10.4324/9781351022668

Easton, M. (2018, February 11). How should we tackle the loneliness epidemic? BBC News. https://www.bbc.com/news/uk-42887932

Floyd, K. (2017). Loneliness Corresponds with Politically Conservative Thought. Research in Psychology and Behavioral Sciences, 5(1). https://doi.org/10.12691/rpbs-5-1-3

Gidron, N., \& Mijs, J. J. B. (2019). Do Changes in Material Circumstances Drive Support for Populist Radical Parties? Panel Data Evidence from the Netherlands during the Great Recession, 2007-2015. European Sociological Review, 35(5). https://doi.org/10.1093/esr/jcz023 
Gierveld, J. de J., Tilburg, T. G. van, \& Dykstra, P. A. (2018). New Ways of Theorizing and Conducting Research in the Field of Loneliness and Social Isolation. In The Cambridge Handbook of Personal Relationships. https://doi.org/10.1017/9781316417867.031

Göpffarth, J. (2021). Activating the socialist past for a nativist future: far-right intellectuals and the prefigurative power of multidirectional nostalgia in Dresden. Social Movement Studies, 20(1). https://doi.org/10.1080/14742837.2020.1722628

Harder, J., \& Krosnick, J. A. (2008). Why do people vote? A psychological analysis of the causes of voter turnout. In Journal of Social Issues (Vol. 64, Issue 3). https://doi.org/10.1111/j.1540-4560.2008.00576.x

Hartmann, J., Kurz, K., \& Lengfeld, H. (2021). OUP accepted manuscript. European Sociological Review, 1-15. https://doi.org/10.1093/esr/jcab024

Hertz, N. (2021). The Lonely Century: How to Restore Human Connection in a World That's Pulling Apart. Currency.

Holt-Lunstad, J. (2017). The Potential Public Health Relevance of Social Isolation and Loneliness: Prevalence, Epidemiology, and Risk Factors. Public Policy \& Aging Report, 27(4). https://doi.org/10.1093/ppar/prx030

Hunger, S., \& Paxton, F. (2021). What's in a buzzword? A systematic review of the state of populism research in political science. Political Science Research and Methods. https://doi.org/10.1017/psrm.2021.44

Ivaldi, G., Lanzone, M. E., \& Woods, D. (2017). Varieties of Populism across a Left-Right Spectrum: The Case of the Front National, the Northern League, Podemos and Five Star Movement. Swiss Political Science Review, 23(4). https://doi.org/10.1111/spsr.12278

Kaltwasser, C. R., \& Van Hauwaert, S. M. (2020). The populist citizen: Empirical evidence from Europe and Latin America. European Political Science Review, 12(1). 
[Hier eingeben]

https://doi.org/10.1017/S1755773919000262

Kurer, T. (2020). The Declining Middle: Occupational Change, Social Status, and the Populist Right. Comparative Political Studies, 53(10-11). https://doi.org/10.1177/0010414020912283

Langenkamp, A. (2021). Enhancing, suppressing or something in between - loneliness and five forms of political participation across Europe. European Societies. https://doi.org/10.1080/14616696.2021.1916554

March, L. (2012). Radical left parties in Europe. Routledge. https://doi.org/10.4324/9780203154878

March, L. (2017). Left and right populism compared: The British case. British Journal of Politics and International Relations, 19(2). https://doi.org/10.1177/1369148117701753

Mudde, C. (2004). The populist zeitgeist. In Government and Opposition (Vol. 39, Issue 4). https://doi.org/10.1111/j.1477-7053.2004.00135.x

Mudde, C. (2007). Populist radical right parties in Europe. In Populist Radical Right Parties in Europe. https://doi.org/10.1017/CBO9780511492037

Mudde, C., \& Kaltwasser, C. R. (2017). Populism: a very short introduction. Oxford University Press. https://doi.org/10.1093/actrade/9780190234874.001.0001

Norris, P., \& Inglehart, R. (2019). Cultural Backlash: Trump, Brexit, and Authoritarian Populism. Cambridge University Press.

Oesch, D. (2006). Coming to grips with a changing class structure: An analysis of employment stratification in Britain, Germany, Sweden and Switzerland. International Sociology, 21(2). https://doi.org/10.1177/0268580906061379

Olds, J., \& Schwartz, R. S. (2009). The Lonely American: Drifting Apart in the Twenty-first 
[Hier eingeben]

Century. Beacon Press.

Olson, M. E. (1972). Social Participation and Voting Turnout: A Multivariate Analysis. American Journal of Sociology, 37(3), 317-333. https://doi.org/https://www.jstor.org/stable/2093471

Putnam, R. D. (2000). Bowling Alone. The Collapse and Revival of American Community. Simon \& Schuster.

Qualter, P., Vanhalst, J., Harris, R., Van Roekel, E., Lodder, G., Bangee, M., Maes, M., \& Verhagen, M. (2015). Loneliness Across the Life Span. Perspectives on Psychological Science, 10(2). https://doi.org/10.1177/1745691615568999

Rooduijn, M., Van Kessel, S., Froio, C., Pirro, A., De Lange, S., Halikiopoulou, D., Lewis, P., Mudde, C., \& Taggart, P. (2019). The PopuList: An Overview of Populist, Far Right, Far Left and Eurosceptic Parties in Europe. www.popu-list.org.

Rooduijn, Matthijs. (2018). What unites the voter bases of populist parties? Comparing the electorates of 15 populist parties. European Political Science Review, 10(3). https://doi.org/10.1017/S1755773917000145

Rooduijn, Matthijs. (2019). State of the field: How to study populism and adjacent topics? A plea for both more and less focus. European Journal of Political Research, 58(1), 362372. https://doi.org/10.1111/1475-6765.12314

Rooduijn, Matthijs, \& Akkerman, T. (2017). Flank attacks: Populism and left-right radicalism in Western Europe. Party Politics, 23(3). https://doi.org/10.1177/1354068815596514

Rooduijn, Matthijs, Burgoon, B., van Elsas, E. J., \& van de Werfhorst, H. G. (2017). Radical distinction: Support for radical left and radical right parties in Europe. European Union Politics, 18(4). https://doi.org/10.1177/1465116517718091 
[Hier eingeben]

Rotenberg, K. J., Addis, N., Betts, L. R., Corrigan, A., Fox, C., Hobson, Z., Rennison, S., Trueman, M., \& Boulton, M. J. (2010). The relation between trust beliefs and loneliness during early childhood, middle childhood, and adulthood. Personality and Social Psychology Bulletin, 36(8). https://doi.org/10.1177/0146167210374957

Rydgren, J. (2009). Social Isolation? Social Capital and Radical Right-wing Voting in Western Europe. Journal of Civil Society, 5(2). https://doi.org/10.1080/17448680903154915

Rydgren, J. (2011). A legacy of “uncivicness"? Social capital and radical right-wing populist voting in Eastern Europe. Acta Politica, 46(2). https://doi.org/10.1057/ap.2011.4

Schwartz, S. H., Caprara, G. V., \& Vecchione, M. (2010). Basic Personal Values, Core Political Values, and Voting: A Longitudinal Analysis. Political Psychology, 31(3). https://doi.org/10.1111/j.1467-9221.2010.00764.x

Smets, K., \& van Ham, C. (2013). The embarrassment of riches? A meta-analysis of individual-level research on voter turnout. Electoral Studies, 32(2). https://doi.org/10.1016/j.electstud.2012.12.006

Spithoven, A. W. M., Bijttebier, P., \& Goossens, L. (2017). It is all in their mind: A review on information processing bias in lonely individuals. In Clinical Psychology Review (Vol. 58). https://doi.org/10.1016/j.cpr.2017.10.003

Steenvoorden, E., \& Harteveld, E. (2018). The appeal of nostalgia: the influence of societal pessimism on support for populist radical right parties. West European Politics, 41(1). https://doi.org/10.1080/01402382.2017.1334138

Stockemer, D., Lentz, T., \& Mayer, D. (2018). Individual Predictors of the Radical RightWing Vote in Europe: A Meta-Analysis of Articles in Peer-Reviewed Journals (19952016). Government and Opposition, 53(3). https://doi.org/10.1017/gov.2018.2 
[Hier eingeben]

Strijbis, O. (2014). Migration background and voting behavior in Switzerland: A sociopsychological explanation. In Swiss Political Science Review (Vol. 20, Issue 4). https://doi.org/10.1111/spsr.12136

Wingrove, C. R., \& Hirschman, A. O. (1971). Exit, Voice, and Loyalty: Responses to Decline in Firms, Organizations, and States. Social Forces, 49(3). https://doi.org/10.2307/3005748

Yann, A., Beasley, E., Cohen, D., \& Foucault, M. (2019). Les Origines du Populisme. Enquête sur un schisme politique et social. Seuil., Éditions du.

Yeginsu, C. (2018). U.K. Appoints a Minister for Loneliness. New York Times. https://doi.org/https://www.nytimes.com/2018/01/17/world/europe/uk-britainloneliness.html

Zhirkov, K. (2014). Nativist but not alienated: A comparative perspective on the radical right vote in Western Europe. Party Politics, 20(2). https://doi.org/10.1177/1354068813511379

Zulianello, M. (2020). Varieties of Populist Parties and Party Systems in Europe: From Stateof-the-Art to the Application of a Novel Classification Scheme to 66 Parties in 33 Countries. In Government and Opposition (Vol. 55, Issue 2). https://doi.org/10.1017/gov.2019.21 
[Hier eingeben]

Figure 1: Populist vote or Nonvoting vs. Mainstream Party: Fixed effects linear probability Models

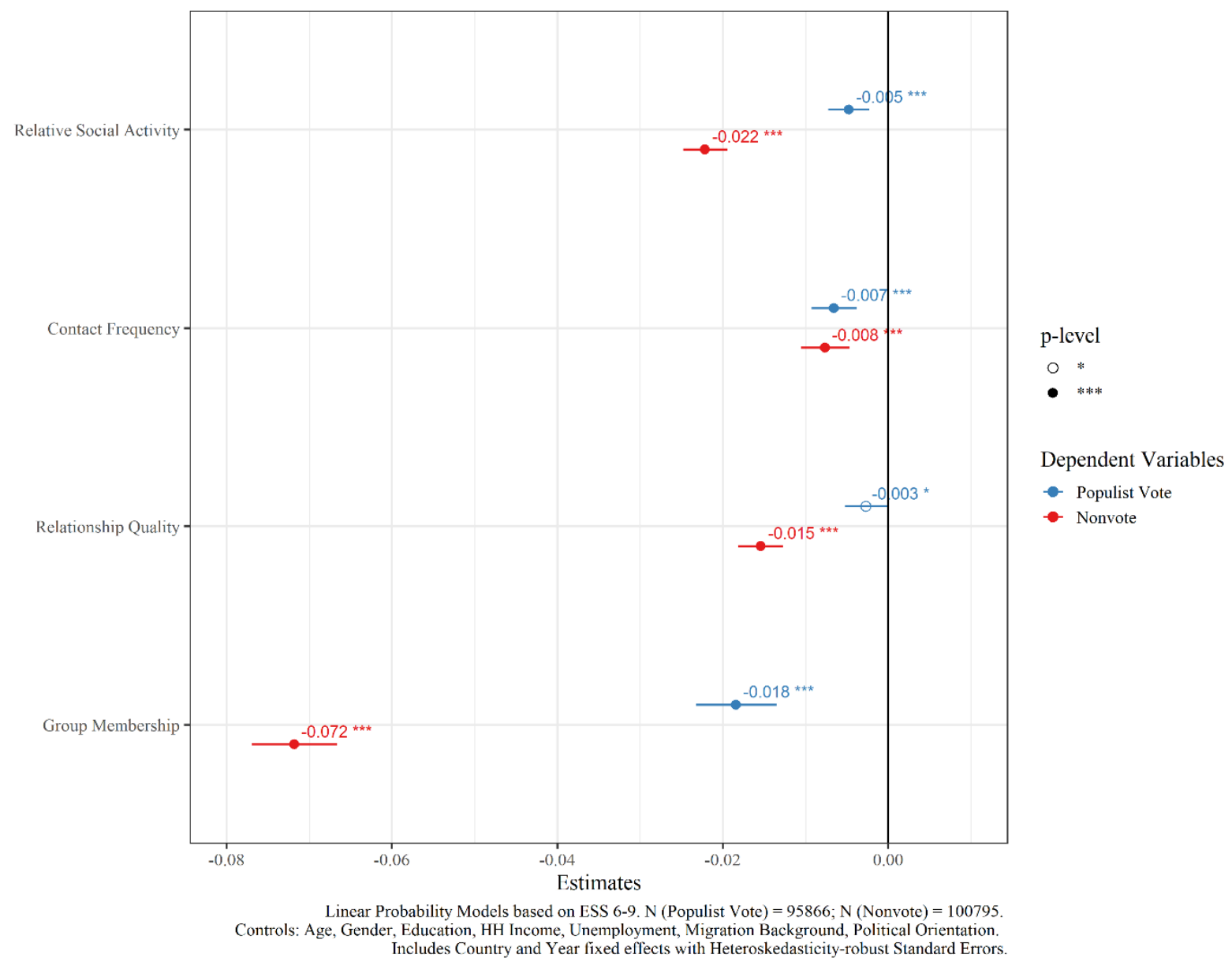


[Hier eingeben]

Figure 2: Differentiated Populist and Social Inclusion: Fixed effects linear probability Models

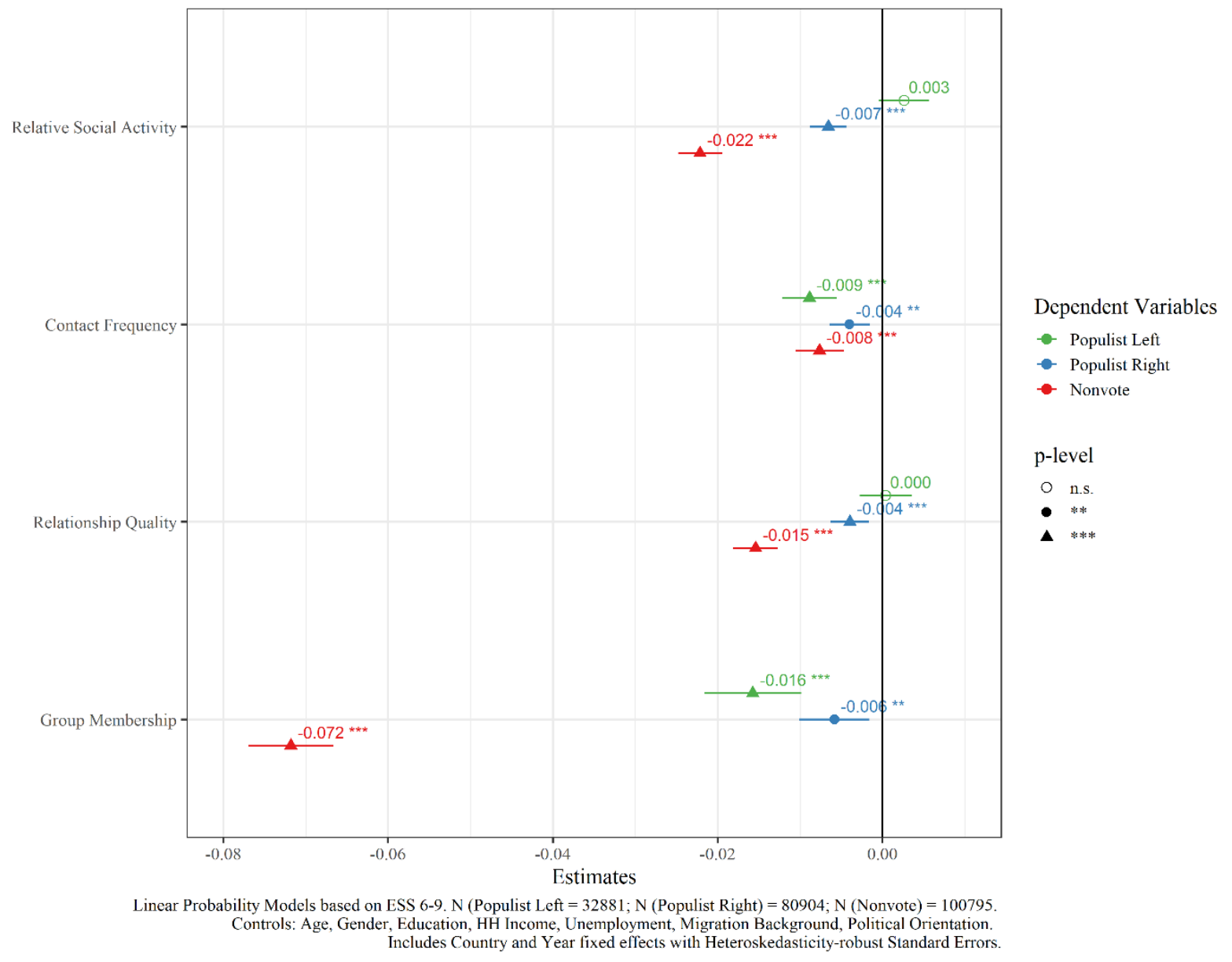


[Hier eingeben]

Table 1: Descriptive Statistics

\begin{tabular}{|c|c|c|c|c|c|c|c|}
\hline & Min & Max & Mean & Std.Dev & Median & N.Valid & $\%$ Valid \\
\hline Populist vs. Mainstream & 0 & 1 & 0.179 & 0.384 & 0 & 95866 & 81.260 \\
\hline Left vs. Mainstream & 0 & 1 & 0.030 & 0.171 & 0 & 81144 & 68.781 \\
\hline Right vs. Mainstream & 0 & 1 & 0.110 & 0.313 & 0 & 88430 & 74.957 \\
\hline Nonvoter vs. Mainstream & 0 & 1 & 0.219 & 0.414 & 0 & 100795 & 85.438 \\
\hline Relative Social Activity & 0 & 4 & 1.735 & 0.919 & 2 & 117974 & 100.000 \\
\hline Contact Frequency & 0 & 6 & 3.784 & 1.522 & 4 & 117974 & 100.000 \\
\hline Relationship Quality & 0 & 6 & 2.874 & 1.427 & 3 & 117974 & 100.000 \\
\hline Group Membership & 0 & 1 & 0.492 & 0.500 & 0 & 117974 & 100.000 \\
\hline Age & 18 & 101 & 51.716 & 17.343 & 52 & 117974 & 100.000 \\
\hline Gender & 1 & 2 & 1.521 & 0.500 & 2 & 117974 & 100.000 \\
\hline Education & 1 & 5 & 3.443 & 1.273 & 3 & 117974 & 100.000 \\
\hline Income & 1 & 6 & 3.411 & 1.653 & 3 & 117974 & 100.000 \\
\hline Unemployed & 0 & 1 & 0.047 & 0.212 & 0 & 117974 & 100.000 \\
\hline Migration background & 0 & 1 & 0.124 & 0.329 & 0 & 117974 & 100.000 \\
\hline HH Size & 1 & 10 & 2.514 & 1.296 & 2 & 117974 & 100.000 \\
\hline Political Orientation & 0 & 10 & 5.176 & 2.179 & 5 & 117974 & 100.000 \\
\hline ESS Round & 1 & 4 & 2.549 & 1.145 & 3 & 117974 & 100.000 \\
\hline
\end{tabular}


[Hier eingeben]

\section{Appendix}

Table 2: Analytical samples by Country

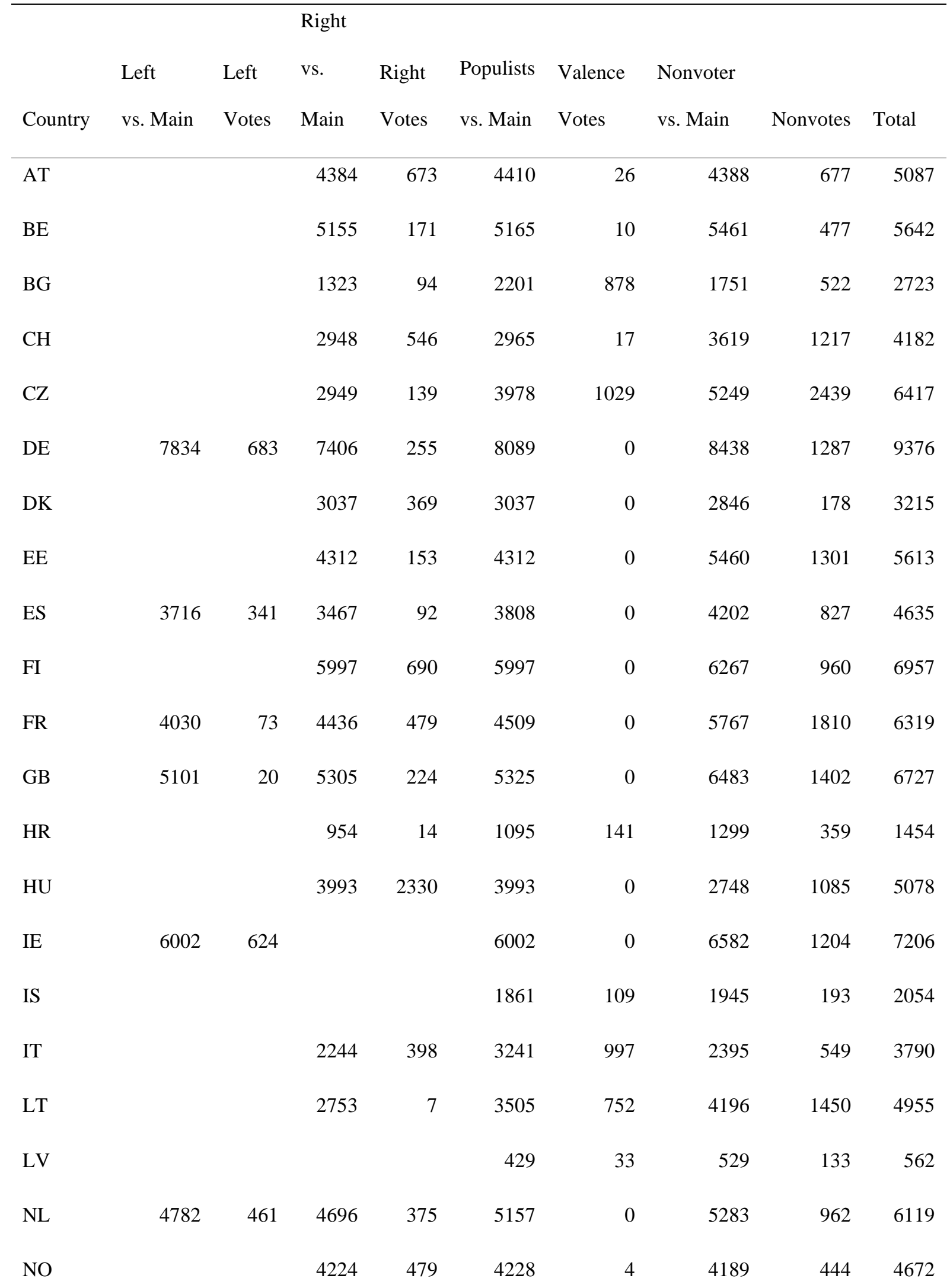




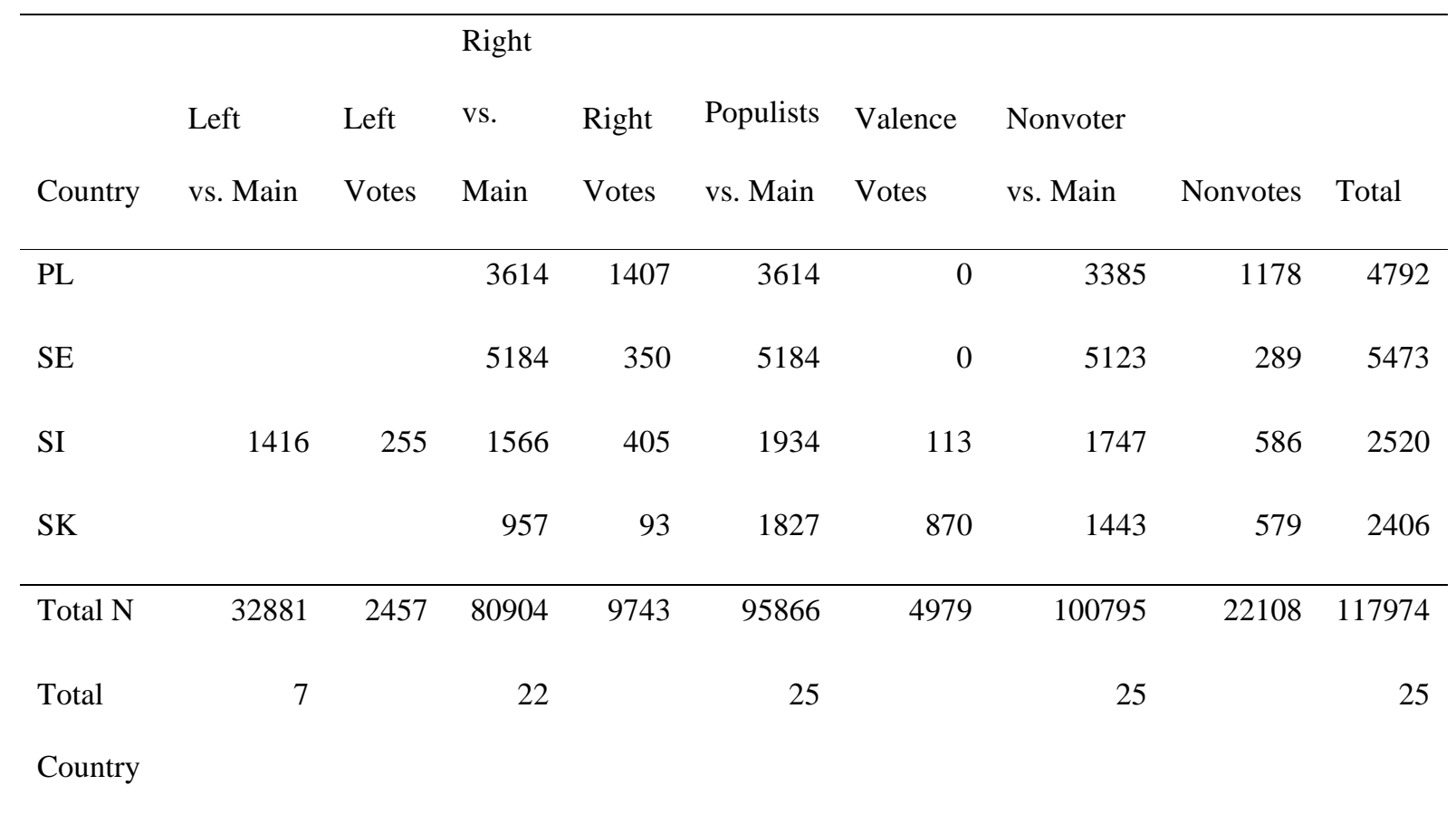

Note: Column 'Left vs. Main' contains the analytical sample used for the model contrasting left-wing populist voters against mainstream voters. 'Left Votes' contains the number of actual votes for the populist left. 
[Hier eingeben]

Table 3:Linear Probability Models of Populist vote or Nonvoting vs. Mainstream Party

\begin{tabular}{|c|c|c|c|c|}
\hline & \multicolumn{2}{|c|}{ Populist vs. Main } & \multicolumn{2}{|c|}{ Nonvoter vs. Main } \\
\hline & M 1 & M 2 & M 3 & M 4 \\
\hline \multirow[t]{2}{*}{ Intercept } & $0.148 * * *$ & $0.180 * * *$ & $0.219 * * *$ & $0.302 * * *$ \\
\hline & $(0.006)$ & $(0.008)$ & $(0.006)$ & $(0.009)$ \\
\hline \multirow[t]{2}{*}{ Relative Social Activity } & $-0.007 * * *$ & $-0.005 * * *$ & $-0.033 * * *$ & $-0.022 * * *$ \\
\hline & $(0.001)$ & $(0.001)$ & $(0.001)$ & $(0.001)$ \\
\hline \multirow[t]{2}{*}{ Contact Frequency } & $-0.004 * *$ & $-0.007 * * *$ & $0.008 * * *$ & $-0.008 * * *$ \\
\hline & $(0.001)$ & $(0.001)$ & $(0.002)$ & $(0.001)$ \\
\hline \multirow[t]{2}{*}{ Relationship Quality } & $-0.008 * * *$ & $-0.003 *$ & $-0.018 * * *$ & $-0.015 * * *$ \\
\hline & $(0.001)$ & $(0.001)$ & $(0.001)$ & $(0.001)$ \\
\hline \multirow[t]{2}{*}{ Group Membership Index } & $-0.025 * * *$ & $-0.018 * * *$ & $-0.101 * * *$ & $-0.072 * * *$ \\
\hline & $(0.003)$ & $(0.002)$ & $(0.003)$ & $(0.003)$ \\
\hline \multirow[t]{2}{*}{ HH Size } & & -0.000 & & $-0.014 * * *$ \\
\hline & & $(0.001)$ & & $(0.001)$ \\
\hline \multirow[t]{2}{*}{ Age } & & $-0.021 * * *$ & & $-0.089 * * *$ \\
\hline & & $(0.001)$ & & $(0.001)$ \\
\hline \multirow[t]{2}{*}{ Female } & & $-0.028 * * *$ & & -0.003 \\
\hline & & $(0.002)$ & & $(0.002)$ \\
\hline \multirow[t]{2}{*}{ ISCED 2} & & $0.026 * * *$ & & -0.008 \\
\hline & & $(0.005)$ & & $(0.006)$ \\
\hline \multirow[t]{2}{*}{ ISCED 3} & & 0.008 & & $-0.069 * * *$ \\
\hline & & $(0.005)$ & & $(0.006)$ \\
\hline \multirow[t]{2}{*}{ ISCED 4} & & $-0.019 * *$ & & $-0.118 * * *$ \\
\hline & & $(0.006)$ & & $(0.007)$ \\
\hline ISCED 5-6 & & $-0.048 * * *$ & & $-0.155 * * *$ \\
\hline
\end{tabular}


[Hier eingeben]

\begin{tabular}{|c|c|c|c|c|}
\hline & \multicolumn{2}{|c|}{ Populist vs. Main } & \multicolumn{2}{|c|}{ Nonvoter vs. Main } \\
\hline & M 1 & M 2 & M 3 & M 4 \\
\hline & & $(0.005)$ & & $(0.006)$ \\
\hline \multirow[t]{2}{*}{ 2nd Quintile } & & -0.004 & & $-0.037 * * *$ \\
\hline & & $(0.004)$ & & $(0.005)$ \\
\hline \multirow[t]{2}{*}{ 3rd Quintile } & & $-0.010 *$ & & $-0.051 * * *$ \\
\hline & & $(0.004)$ & & $(0.005)$ \\
\hline \multirow[t]{2}{*}{ 4th Quintile } & & $-0.024 * * *$ & & $-0.078 * * *$ \\
\hline & & $(0.004)$ & & $(0.005)$ \\
\hline \multirow[t]{2}{*}{ 5th Quintile } & & $-0.052 * * *$ & & $-0.091 * * *$ \\
\hline & & $(0.005)$ & & $(0.005)$ \\
\hline \multirow[t]{2}{*}{ Missing Income } & & $-0.047 * * *$ & & $-0.045 * * *$ \\
\hline & & $(0.005)$ & & $(0.005)$ \\
\hline \multirow[t]{2}{*}{ Unemployed } & & $0.042 * * *$ & & $0.075 * * *$ \\
\hline & & $(0.007)$ & & $(0.007)$ \\
\hline \multirow[t]{2}{*}{ Migration Background } & & -0.006 & & $0.049 * * *$ \\
\hline & & $(0.003)$ & & $(0.004)$ \\
\hline \multirow[t]{2}{*}{ Pol. Orientation } & & $0.044 * * *$ & & 0.001 \\
\hline & & $(0.001)$ & & $(0.001)$ \\
\hline $\mathrm{R}^{\wedge} 2$ & 0.151 & 0.177 & 0.093 & 0.152 \\
\hline Adj. $R^{\wedge} 2$ & 0.151 & 0.176 & 0.093 & 0.152 \\
\hline Num. obs. & 95866 & 95866 & 100795 & 100795 \\
\hline
\end{tabular}

Note: $* p<.05 ; * * p<.01 ; * * * p<.001$; Linear Probability Models with Country and Year Fixed Effects. Continuous variables were standardized. 
[Hier eingeben]

Table 4: Linear Probability Models of Populism, Differentiated

\begin{tabular}{|c|c|c|c|c|}
\hline & \multicolumn{2}{|c|}{$\underline{\text { Left Populist vs. Main }}$} & \multicolumn{2}{|c|}{$\underline{\text { Right Populist vs. Main }}$} \\
\hline & M 5 & M 6 & M 7 & M 8 \\
\hline \multirow[t]{3}{*}{ Intercept } & $0.090 * * *$ & $0.099 * * *$ & 0.127 & $0.172 * * *$ \\
\hline & & & $* * *$ & \\
\hline & $(0.004)$ & $(0.007)$ & $(0.006)$ & $(0.008)$ \\
\hline \multirow[t]{3}{*}{ Relative Social Activity } & -0.000 & 0.003 & -0.008 & $-0.007 * * *$ \\
\hline & & & $* * *$ & \\
\hline & $(0.002)$ & $(0.002)$ & $(0.001)$ & $(0.001)$ \\
\hline \multirow[t]{2}{*}{ Contact Frequency } & $-0.008 * * *$ & $-0.009 * * *$ & -0.002 & $-0.004 * *$ \\
\hline & $(0.002)$ & $(0.002)$ & $(0.001)$ & $(0.001)$ \\
\hline \multirow[t]{3}{*}{ Relationship Quality } & 0.001 & 0.000 & -0.010 & $-0.004 * * *$ \\
\hline & & & $* * *$ & \\
\hline & $(0.002)$ & $(0.002)$ & $(0.001)$ & $(0.001)$ \\
\hline \multirow[t]{3}{*}{ Group Membership Index } & $-0.025 * * *$ & $-0.016 * * *$ & -0.012 & $-0.006 * *$ \\
\hline & & & $* * *$ & \\
\hline & $(0.003)$ & $(0.003)$ & $(0.002)$ & $(0.002)$ \\
\hline \multirow[t]{2}{*}{ HH Size } & & -0.001 & & -0.001 \\
\hline & & $(0.002)$ & & $(0.001)$ \\
\hline \multirow[t]{2}{*}{ Age } & & $-0.008 * * *$ & & $-0.016 * * *$ \\
\hline & & $(0.002)$ & & $(0.001)$ \\
\hline \multirow[t]{2}{*}{ Female } & & $-0.014 * * *$ & & $-0.026 * * *$ \\
\hline & & $(0.003)$ & & $(0.002)$ \\
\hline \multirow[t]{2}{*}{ ISCED 2} & & $0.015 * *$ & & $0.018 * * *$ \\
\hline & & $(0.006)$ & & $(0.005)$ \\
\hline ISCED 3 & & 0.006 & & -0.005 \\
\hline
\end{tabular}


[Hier eingeben]

\begin{tabular}{|c|c|c|c|c|}
\hline & \multicolumn{2}{|c|}{$\underline{\text { Left Populist vs. Main }}$} & \multicolumn{2}{|c|}{ Right Populist vs. Main } \\
\hline & M 5 & M 6 & M 7 & M 8 \\
\hline & & $(0.005)$ & & $(0.005)$ \\
\hline \multirow[t]{2}{*}{ ISCED 4} & & 0.005 & & $-0.035 * * *$ \\
\hline & & $(0.008)$ & & $(0.006)$ \\
\hline \multirow[t]{2}{*}{ ISCED 5-6 } & & -0.000 & & $-0.060 * * *$ \\
\hline & & $(0.005)$ & & $(0.005)$ \\
\hline \multirow[t]{2}{*}{ 2nd Quintile } & & $-0.015 * *$ & & -0.002 \\
\hline & & $(0.005)$ & & $(0.004)$ \\
\hline \multirow[t]{2}{*}{ 3rd Quintile } & & $-0.024 * * *$ & & $-0.008 *$ \\
\hline & & $(0.005)$ & & $(0.004)$ \\
\hline \multirow[t]{2}{*}{ 4th Quintile } & & $-0.039 * * *$ & & $-0.017 * * *$ \\
\hline & & $(0.005)$ & & $(0.004)$ \\
\hline \multirow[t]{2}{*}{ 5th Quintile } & & $-0.051 * * *$ & & $-0.038 * * *$ \\
\hline & & $(0.005)$ & & $(0.004)$ \\
\hline \multirow[t]{2}{*}{ Missing Income } & & $-0.043 * * *$ & & $-0.034 * * *$ \\
\hline & & $(0.005)$ & & $(0.004)$ \\
\hline \multirow[t]{2}{*}{ Unemployed } & & $0.058 * * *$ & & $0.016 * *$ \\
\hline & & $(0.010)$ & & $(0.006)$ \\
\hline \multirow[t]{2}{*}{ Migration Background } & & -0.000 & & $-0.011 * * *$ \\
\hline & & $(0.004)$ & & $(0.003)$ \\
\hline \multirow[t]{2}{*}{ Pol. Orientation } & & $-0.055 * * *$ & & $0.067 * * *$ \\
\hline & & $(0.002)$ & & $(0.001)$ \\
\hline $\mathrm{R}^{\wedge} 2$ & 0.032 & 0.083 & 0.175 & 0.231 \\
\hline Adj. $R^{\wedge} 2$ & 0.032 & 0.083 & 0.174 & 0.231 \\
\hline Num. obs. & 32881 & 32881 & 80904 & 80904 \\
\hline
\end{tabular}




\section{[Hier eingeben]}

Note: *p<.05; **p<.01; ***p<.001; Linear Probability Models with Country and Year Fixed Effects. Continuous variables were standardized. 